\title{
Moderating Effect of Inflation on the Influence of Financial Performance on the Growth of Islamic Banking in Indonesia
}

\author{
Abid Djazuli $^{\mathrm{a}}$, Mister Candera ${ }^{\mathrm{b}}$ \\ ${ }^{\mathrm{a}, \mathrm{b}}$ Universitas Muhammadiyah Palembang \\ Correspondence Email: abid_djazuli@um-palembang.ac.id
}

\begin{abstract}
Islamic banking is one of the financial institutions whose activities are financial intermediation between the owners of capital and those who need capital. This study was conducted to know and analyze the impact of inflation as a moderating influence of financial performance on the growth of Islamic banking in Indonesia. The financial performance used consists of return on assets (ROA), non-performing financing (NPF), net operating margin (NOM), capital adequacy ratio (CAR), financing to Deposit Ratio (FDR), and operating expenses for operating income (BOPO). The data used is secondary data, obtained from the results of financial reports published on the official website of the Otoritas Jasa Keuangan (OJK) from January 2015 to December 2019. The analysis results show that, in general, inflation cannot moderate the influence of financial performance on rbanking growth - Sharia in Indonesia. Inflation can only be a predictor of the effect of return On Assets and net operating margin on the growth of Islamic banking in Indonesia. Meanwhile, the variables of non-performing financing (NPF), capital adequacy ratio (CAR), financing to deposit ratio (FDR), and operating expenses for operating income (BOPO) are not able to be a moderator or as a predictor.
\end{abstract}

Keywords: Financial Performance; Inflation; Islamic Banking Growth.

\section{How to Cite}

Djazuli, A. \& Candera, M. (2020). Moderating effect of inflation on the influence of financial performance on the growth of Islamic Banking in Indonesia. International Journal of Finance Research, 1(2). 124-143. DOI : https://doi.org/10.47747/ijfr.v1i2.259.

\section{Introduction}

The new era 4.0 lately we hear more and more often. This shows that technological changes are increasingly rapid; as a result, companies in facing their competitors must be able to adapt. An increasingly open economic system opens the door wide for foreign competitors to enter and exit. This challenge requires anyone who will do business to innovate on things that attract customers.

This development is not only in companies that produce products but also in banking companies. Currently, banking companies must be able to provide non-physical money services. The payment system that used to be done in cash has begun to shift to non-cash. 
Banking customers are very interested in banks that provide many application-based non-cash services such as M-Banking or the like. M-Banking services can make it easier for customers to transact; through this service, customers can make payments, purchases, top-ups, etc. This can attract prospective customers to determine what bank to choose as a place to invest, and this is also suspected to be one of the low public interests in investing in Islamic banking. In Islamic banking, m-banking services are still not fully able to compete with conventional bank services. In addition, the number of sharia banking ATM services is also still lacking.

Islamic banking has not been able to thrive in Indonesian society, in which most of the population is Muslim. The following is data on the growth of Islamic banking in Indonesia.

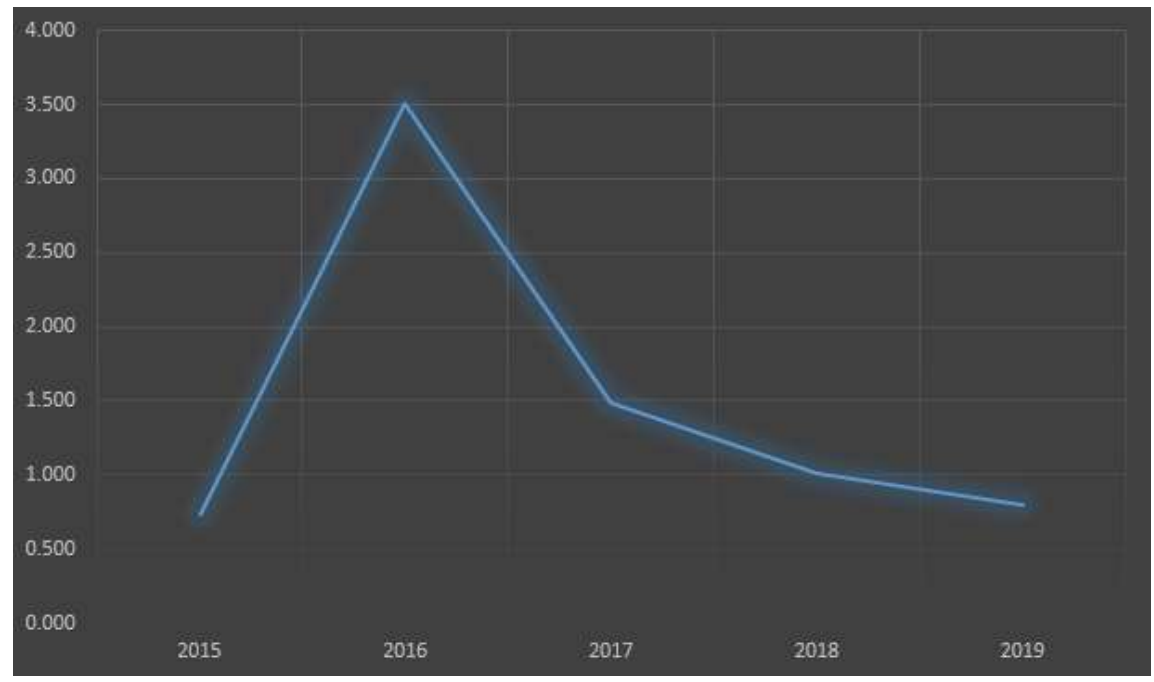

Figure 1. Growth of Islamic banking

The picture 1 above shows the growth of Islamic banking from 2015 to 2019. The highest growth occurred in 2016, while in the following years, the growth of Islamic banking experienced a significant decline. It can be seen from the figure that the growth of Islamic banking tends to decline. It is very interesting to conduct further studies, especially regarding what factors affect the growth of Islamic banking and how macroeconomic conditions (inflation) affect this growth.

Several factors can affect the growth of Islamic banking, one of which is financial performance. In theory, financial performance, according to Fahmi (2017), is an analysis carried out to assess the extent to which a company implements by using financial implementation rules correctly and adequately. Meanwhile, Sutrisno (2013) states that financial performance is an achievement achieved by a company in a certain period that reflects the level of health of the company. Financial performance can be seen from financial ratios such as liquidity ratios, solvency ratios, and profitability ratios (Kasmir, 2014).

Several previous researchers found that the factors that influence the company's growth are return on assets; net operating margins; non-performing financing (Candera, Amir, \& Artis, 2015, Supriyanto \& Sari, 2019, Setyawati \& Suroso, 2016); capital adequacy ratio (Setyawati \& Suroso, 2016 and Ihsan, 2019); financing to deposit ratio (Candera, Amir, \& Artis, 2015, 
Supriyanto \& Sari, 2019, and Safrida \& Abror, 2011); and Operating Expenses Operating Income (Ihsan, 2019). In contrast to the results of the study, return on assets (Supriyanto \& Sari, 2019); Non Performing Financing (Dhiba \& Esya, 2019, Setiawan \& Hanryono, 2016, Aisy \& Mawardi, 2016 and Syafrida \& Abror, 2011); net operating margin (Ihsan, 2019); capital adequacy ratio (Setiawan \& Hanryono, 2016, Ichsan, Amri, \& Rahmatia, 2014); financing to deposit ratio (Setyawati \& Suroso, 2016, Aisy \& Mawardi, 2016 and Setiawan \& Hanryono, 2016); and Operating Expenses Operating Income (Dhiba and Esya, 2019, Ichsan, Amri, \& Rahmatia, 2014, and Setiawan \& Hanryono, 2016) also found that these variables had no effect on company growth.

This research is different from previous studies by using inflation as a moderating variable. This is presumably because inflation is a macro condition that is closely related to national economic conditions. High inflation describes economic conditions that are not good. Therefore the government is trying in such a way so that the inflation rate is stable and in line with the government's target. Aisy \& Mawardi's (2016) research found that external factors (inflation) significantly affected asset growth. In contrast to the results of this study, Setiawan \& Hanryono (2016) found that inflation was not significant in influencing company growth.

\section{Literature Review}

\subsection{Financial Performance}

According to Fahmi (2011), financial performance describes a company's financial condition, which is analyzed with financial analysis tools to be known about a company's good and bad financial conditions that reflect work performance in a certain period. In this study, the financial performance used consists of return on assets (ROA), non-performing financing (NPF), net operating margin (NOM), capital adequacy ratio (CAR), financing to deposit ratio (FDR), and Operating Expenses/Revenues. In more detail, it can be explained as follows.

1. Return on assets (ROA) is a ratio used to show how much the contribution of assets creates net income. This ratio is used to measure how much net income is generated from each rupiah embedded in total assets (Hery, 2017).

2. Non-performing financing (NPF) is a ratio that shows the ability of bank management to manage non-performing financing provided by banks.

3. Net operating margin (NOM) is a ratio used to measure the ability of bank management to manage their productive assets to generate revenue sharing.

4. Capital adequacy ratio (CAR), in the regulation of Bank Indonesia, is a ratio that shows how much total bank assets that contain risks are also financed from their capital and obtaining funds from sources outside the bank.

5. Financing to deposit ratio (FDR) is one of the liquidity ratios that compare the composition of funds channelled to financing with third party funds that have been collected.

6. Operational expenses/operational income (BOPO) is one of the efficiency ratios used to measure a bank's ability to run its business operations.

\subsection{Inflation}

According to Sukirno (2012), inflation increases prices generally prevailing in an economy 
from one period to another. In connection with this research, the inflation rate used is the Consumer Price Index. In general, the formula used to determine the inflation rate is:

$$
I N F_{t}=\frac{C P I_{n}-C P I_{n-1}}{C P I_{n-1}} \times 100 \%
$$

\subsection{Islamic Banking Growth}

According to Priyo (2013), growth is a company asset where assets are assets used for operational activities company. The faster the company's growth in generating profits, the greater the expenditure needed to finance the company's growth, so it must limit dividends to save funds in the company for growth investment.

In general, the growth formula can be calculated using the following formula.

$$
\operatorname{Asset}_{t}=\frac{\operatorname{Assets}_{n}-\operatorname{Asset}_{n-1}}{\operatorname{Asset}_{n-1}}
$$

\section{Research Method}

This research is associative research. According to Sugiyono (2014), associative research aims to determine the relationship between two or more variables. The data used is secondary data from financial reports published on the Otoritas Jasa Keuangan (OJK).

The variables used in this study consisted of the dependent variable, the independent variable, and the moderating variable. The dependent variable referred to in this study is the Islamic banking growth variable; The independent variables consist of return on assets (ROA), nonperforming financing (NPF), net operating margin (NOM), capital adequacy ratio (CAR), financing to deposit ratio (FDR), and operating expenses/revenues. Meanwhile, the moderating variable is inflation.

Analysis of the data used is the Moderated Regression Analysis (MRA). Ghozali (2013) states that Moderated Regression Analysis (MRA) is an analytical approach that maintains sample integrity and provides a basis for controlling the influence of moderator variables. However, before the MRA analysis, the data were tested for classical assumptions using the normality test.

The MRA analysis model can be reflected as follows.

$$
\begin{aligned}
& Y=\alpha+\beta_{1} R O A+\beta_{4} \operatorname{Inf}+\beta_{5} R O A * \operatorname{Inf} \\
& Y=\alpha+\beta_{2} N P F+\beta_{4} \operatorname{Inf}+\beta_{6} N P F * \operatorname{Inf} \\
& Y=\alpha+\beta_{3} N O M+\beta_{4} \operatorname{Inf}+\beta_{7} N O M * \operatorname{Inf} \\
& Y=\alpha+\beta_{1} C A R+\beta_{4} \operatorname{Inf}+\beta_{5} C A R * \operatorname{Inf} \\
& Y=\alpha+\beta_{2} F D R+\beta_{4} \operatorname{Inf}+\beta_{6} F D R * \operatorname{Inf} \\
& Y=\alpha+\beta_{3} B O P O+\beta_{4} \operatorname{Inf}+\beta_{7} B O P O * \operatorname{Inf}
\end{aligned}
$$


According to Ghazali (2013), the classification of moderating variables is as follows:

Pure moderator. This can be identified through the coefficients $\beta_{2}$ and $\beta_{3}$, that is, if the coefficient $\beta_{2}$ is declared insignificant, but the coefficient $\beta_{3}$ is significant.

1. Quasi moderator, identified through the coefficients $\beta_{2}$ and $\beta_{3}$ that is, if the coefficient $\beta_{2}$ is significant and the coefficient $\beta_{2}$ is also significant.

2. Homologies, identified through the coefficients $\beta_{2}$ and $\beta_{3}$ are if the coefficient $\beta_{2}$ is declared insignificant and the coefficient $\beta_{3}$ is also not significant.

3. Moderation Predictor, identified through the coefficients $\beta_{2}$ and $\beta_{3}$ that is if the coefficient $\beta_{2}$ is significant and the coefficient $\beta_{3}$ is not significant.

\section{Findings and Discussions}

4.1. Descriptive Statistic

descriptive analysis of research variables can be seen in the following Tables 1.

Table 1. Descriptive Statistics ROA Variable

\begin{tabular}{lcc}
\hline Descriptive Statistics & $R O A$ \\
\hline$N$ & Valid & 60 \\
Mean & Missing & 0 \\
Median & 17.3256 \\
Std. Deviation & 16.8940 \\
Skewness & 2.38456 \\
Std. Error of Skewness & .287 \\
Kurtosis & .309 \\
Std. Error of Kurtosis & -1.466 \\
\hline
\end{tabular}

The Table 1 above shows that the average return on asset variable is 17.32; the median of 16.89; and the standard deviation of 2.38. The description of the non-performance financing variable can be seen in the following Table 2.

Table 2. Descriptive Statistics NPF Variable

\begin{tabular}{lcc}
\hline Descriptive Statistics & $N P F$ \\
\hline$N$ & Valid & 60 \\
Mean & Missing & 0 \\
Median & .9932 \\
Std. Deviation & .9980 \\
Skewness & .41309 \\
Std. Error of Skewness & .148 \\
Kurtosis & .309 \\
Std. Error of Kurtosis & -1.151 \\
\hline
\end{tabular}


The Table 2 above shows that the average non-performance financing variable is 0.99; the median of 0.99; and the standard deviation of 0.413. Description of the net operational margin variable can be seen in the following Table 3.

Table 3. Descriptive Statistics NOM Variable

\begin{tabular}{lcc}
\hline Descriptive Statistics & NOM \\
\hline$N$ & Valid & 60 \\
Mean & Missing & 0 \\
Median & 4.5919 \\
Std. Deviation & 4.7550 \\
Skewness & .80156 \\
Std. Error of Skewness & -.281 \\
Kurtosis & .309 \\
Std. Error of Kurtosis & -1.097 \\
\hline
\end{tabular}

The Table 3 above shows that the average net operational margin variable is 4.59 ; the median is 4.76; and the standard deviation of 0.80 . Description of the variable capital adequacy ratio can be seen in the following Table 4.

Table 4. Descriptive Statistics CAR Variable

\begin{tabular}{lcc}
\hline Descriptive Statistics & $C A R$ \\
\hline$N$ & Valid & 60 \\
Mean & Missing & 0 \\
Median & & 83.5406 \\
Std. Deviation & 81.8670 \\
Skewness & 4.64122 \\
Std. Error of Skewness & .331 \\
Kurtosis & .309 \\
Std. Error of Kurtosis & -1.462 \\
\hline
\end{tabular}

The table 4 above shows that the average capital adequacy ratio variable is 83.54 ; the median is 81,879 ; and the standard deviation of 4.64. Description of the variable financing to deposit ratio can be seen in the following Table 5.

Table 5. Descriptive Statistics FDR Variable

\begin{tabular}{lcc}
\hline Descriptive Statistics & $F D R$ \\
\hline$N$ & Valid & 60 \\
Mean & Missing & 0 \\
Median & & 92.3389 \\
Std. Deviation & 93.5800 \\
Skewness & 4.14408 \\
Std. Error of Skewness & & -.374 \\
& & .309
\end{tabular}


The table 5 above shows that the average financing to deposit ratio variable is 92.34 ; the median is 93.58; and the standard deviation of 4.14. Variable description of operationalization expenses to operationalization income can be seen in the following Table 6 .

Table 6. Descriptive Statistics BOPO Variable

\begin{tabular}{lcc}
\hline Descriptive Statistics & Valid & BOPO \\
\hline$N$ & Missing & 60 \\
Mean & & 1.1122 \\
Median & 1.1055 \\
Std. Deviation & .47365 \\
Skewness & .111 \\
Std. Error of Skewness & .309 \\
Kurtosis & -1.223 \\
Std. Error of Kurtosis & .608 \\
\hline
\end{tabular}

The table 6 above shows that the average operating expense variable operating income is 1.11; the median is 1.10; and the standard deviation of 0.47 . The description of the inflation variable can be seen in the following Table 7.

Table 7. Descriptive Statistics Inflasion Variable

\begin{tabular}{|c|c|c|}
\hline Descriptive Statistics & & INFLASI \\
\hline & Valid & 60 \\
\hline$N$ & Missing & 0 \\
\hline Mean & & 3.9898 \\
\hline Median & & 3.4050 \\
\hline Std. Deviation & & 1.37212 \\
\hline Skewness & & 1.472 \\
\hline Std. Error of Skewness & & .309 \\
\hline Kurtosis & & .825 \\
\hline Std. Error of Kurtosis & & .608 \\
\hline
\end{tabular}

The Table 7 above shows that the average inflation variable is 3.99 ; the median is 3.41 ; and the standard deviation of 1.37. Description of Islamic banking growth variables can be seen in the following Table 8 . 
Table 8. Descriptive Statistics Growth Variable

\begin{tabular}{lcc}
\hline Descriptive Statistics & GROWTH \\
\hline$N$ & Valid & 60 \\
Mean & Missing & 0 \\
Median & 1.1256 \\
Std. Deviation & .8360 \\
Skewness & 2.37199 \\
Std. Error of Skewness & .730 \\
Kurtosis & .309 \\
Std. Error of Kurtosis & 1.093 \\
\hline
\end{tabular}

The Table 8 above shows that the average Islamic Banking Growth variable is 1.12; the median is 0.84 ; and the standard deviation of 2.37 .

\subsection{Normality Test Normality}

The test is used to determine whether the variables used are normally distributed or not. If the significance value of Kolmogorov-Smirnov is greater than the alpha value of 0.05 , it can be concluded that the data is normally distributed. Conversely, if the significance value is smaller than the alpha value of 0.05 , it can be concluded that the data is not normally distributed. The results of the normality analysis can be seen in the following Table 9.

Table 9. Normality test results for

\begin{tabular}{cc}
\hline variables & Sig \\
\hline ROA value & 0.200 \\
NPM & 0.095 \\
DER & 0.187 \\
Growth & 0.200 \\
Inflation & 0.200 \\
\hline
\end{tabular}

The results of the normality analysis using the Kolmogorov-Smirnov above show that the significance value of each variable is greater than the alpha value of 0.05 . So it can be concluded that all research variables are normally distributed.

\section{Moderated Regression Analysis (MRA)}

3.2.1. the moderating effect of the inflation variable on the influence of the financial performance of the roa indicator on the growth of islamic banking in indonesia

The results of the moderated regression analysis (MRA) analysis can be seen in the following table. 
Table 10. The results of the MRA analysis of inflation on the effect of ROA on the growth of Islamic banking

\begin{tabular}{ccccccccccc}
\hline & & \multirow{2}{*}{$\begin{array}{c}* \\
\text { Model }\end{array}$} & $R$ & Adjusted $R$ & \multirow{2}{*}{$\begin{array}{c}\text { Std. Error of the } \\
\text { Square }\end{array}$} & \multicolumn{4}{c}{ Change Statistics } \\
\cline { 7 - 11 } & & & Square & Estimate & $\begin{array}{c}\text { R Square } \\
\text { Change }\end{array}$ & $\begin{array}{c}F \\
\text { Change }\end{array}$ & $d f 1$ & $d f 2$ & $\begin{array}{c}\text { Sig. F } \\
\text { Change }\end{array}$ \\
\hline 1 & $.038^{a}$ & .001 & -.016 & 2.39070 & .001 & .085 & 1 & 58 & .771 \\
2 & $.241^{b}$ & .058 & .025 & 2.34194 & .057 & 3.440 & 1 & 57 & .069 \\
3 & $.262^{c}$ & .069 & .019 & 2.34993 & .010 & .613 & 1 & 56 & .437 \\
\hline
\end{tabular}

Table 10 above can be explained as follows:

a) Model 1, when entering the ROA variable, the contribution is predictor 1.6 per cent. The significance value of $\mathrm{F}$ is 0.771 , which is greater than the alpha value of 0.1 $(0.771>0.1)$, meaning that ROA cannot predict the growth of Islamic banking significantly.

b) Model 2, inflation is able to predict the growth of Islamic banking, this can be seen from the $\mathrm{F}$ change value of $3,440(\mathrm{p}=0,69 ; \mathrm{p}<0,1)$. This means that significant inflation predicts the growth of Islamic banking.

c) Model 3, Moderation 1 (inflation * ROA), can predict the growth variable of Islamic banking by 1.9 per cent. Reducing the growth of Islamic banking by 6 per cent. The value of $F$ change is $0.613(p=0.437 ; p>0.1)$. This means that moderation 1 is not able to predict the growth variable of Islamic banking significantly.

Based on the above model, it can be concluded that both individual ROA cannot predict the growth of Islamic banking significantly. Inflation cannot moderate the influence of ROA on the growth of Islamic banking. Inflation can be a predictor of moderation or an independent variable.

Table 11. First MRA Coefficient

\begin{tabular}{lcc} 
& \multirow{2}{*}{ Model } & \multicolumn{2}{c}{ Unstandardized Coefficients } \\
\cline { 2 - 3 } & $B$ & Std. Error \\
\hline (Constant) & 2,366 & 2,664 \\
ROA & 1,592 & 3,414 \\
Inflation & .694 & .031 \\
Interaction ROA \& Inflation & -.799 & 1,020 \\
\hline
\end{tabular}

Based on the table above, it can be arranged first MRA equation model as follows.

$$
\begin{aligned}
& \mathrm{Y}=\alpha+\beta_{1} \mathrm{ROA}+\beta_{4} \operatorname{Inf}+\beta_{5} \mathrm{ROA} * \operatorname{Inf} \\
& \mathrm{Y}=2,366+1,592 \mathrm{ROA}+0,694 \mathrm{Inf}-0,799 \mathrm{ROA} * \operatorname{Inf}
\end{aligned}
$$

From the model, it can be concluded that inflation is a moderating variable that can weaken the influence of ROA on the growth of Islamic banking. 
3.2.2. The moderating effect of the inflation variable on the influence of indicators nonperforming financing on the growth of Islamic banking in Indonesia

The results of the moderated regression analysis (MRA) analysis can be seen in the following Table 12.

Table 12. The results of the MRA analysis of inflation on the effect of NPF on the growth of Islamic banking

\begin{tabular}{|c|c|c|c|c|c|c|c|c|c|}
\hline \multirow[b]{2}{*}{ Model } & \multirow[b]{2}{*}{$R$} & \multirow{2}{*}{$\begin{array}{c}R \\
\text { Square }\end{array}$} & \multirow{2}{*}{$\begin{array}{l}\text { Adjusted } R \\
\text { Square }\end{array}$} & \multirow{2}{*}{$\begin{array}{l}\text { Std. Error of the } \\
\text { Estimate }\end{array}$} & \multicolumn{5}{|c|}{ Change Statistics } \\
\hline & & & & & $\begin{array}{l}\text { R Square } \\
\text { Change }\end{array}$ & $\begin{array}{c}F \\
\text { Change }\end{array}$ & $d f 1$ & $d f 2$ & $\begin{array}{l}\text { Sig. } F \\
\text { Change }\end{array}$ \\
\hline 1 & $.160^{a}$ & .026 & .009 & 2.36165 & .026 & 1.523 & 1 & 58 & .222 \\
\hline 2 & $201^{b}$ & .040 & .007 & 2.36426 & .015 & .872 & 1 & 57 & .354 \\
\hline 3 & $.213^{c}$ & .045 & -.006 & 2.37910 & .005 & .291 & 1 & 56 & .592 \\
\hline
\end{tabular}

Table 12 above can be explained as follows:

a) Model 1, when entering the NPF variable, the predictor contribution is 0.9 per cent. The $F$ value of $1.523(\mathrm{p}=0.222 ; \mathrm{p}>0.1)$ means that the NPF cannot predict significantly.

b) Model 2, when entering the variable inflation predictor contribution, decreased to 0.7 per cent. The value of $F$ change is $0.872(p=0.354 ; p>0.1)$. This means that inflation does not significantly predict the growth of Islamic banking independently.

c) Model 3, Moderation 2 (inflation * NPF), can predict the growth variable of Islamic banking by 0.6 per cent. The value of $F$ change is $0.291(p=0.592 ; p>0.1)$. This means that moderation 2 is not able to predict the growth variable of Islamic banking significantly.

Based on the above model, it can be concluded that both individual NPF and inflation cannot significantly predict the growth of Islamic banking and inflation and cannot moderate the influence between NPF and growth of Islamic banking.

Table 13. The second MRA Coefficient

\begin{tabular}{lcc}
\hline \multirow{2}{*}{ Model } & \multicolumn{2}{c}{ Unstandardized Coefficients } \\
\cline { 2 - 3 } (Constant) & $B$ & Std. Error \\
NPF & $-2,376$ & 10,550 \\
Inflation & .821 & 2,024 \\
Interaction of NPF \& Inflation & 1,524 & 3,296 \\
\hline
\end{tabular}

Based on the table above, the second MRA equation model can be arranged as follows.

$\mathrm{Y}=\alpha+\beta_{1} \mathrm{npf}+\beta_{4} \operatorname{Inf}+\beta_{5} \mathrm{npf} * \operatorname{Inf}$

$\mathrm{Y}=-2,376+0,821 \mathrm{npf}+1,524 \mathrm{Inf}-0.336 \mathrm{npf} *$ Inf. 
From this model, it can be concluded that inflation is a moderating variable that can weaken the influence of NPF on Islamic banking growth.

3.2.3. The moderating effect of the inflation variable on the influence of the financial performance of the indicator net operating margin (NOM)on the growth of Islamic banking in Indonesia

The results of the Moderated Regression Analysis (MRA) analysis can be seen in the following Table 14.

Table 14. MRA analysis results of inflation on the effect of NOM on the growth of Islamic banking

\begin{tabular}{cccccccccc}
\hline Model & $R$ & \multirow{2}{*}{$\begin{array}{c}R \\
\text { Square }\end{array}$} & $\begin{array}{c}\text { Adjusted } R \\
\text { Square }\end{array}$ & $\begin{array}{c}\text { Std. Error of } \\
\text { the Estimate }\end{array}$ & $\begin{array}{c}\text { R Square } \\
\text { Change }\end{array}$ & $\begin{array}{c}F \\
\text { Change }\end{array}$ & $d f 1$ & $d f 2$ & $\begin{array}{c}\text { Sig. } F \\
\text { Change }\end{array}$ \\
\hline 1 & $.053^{a}$ & .003 & -.014 & 2.38904 & .003 & .166 & 1 & 58 & .685 \\
2 & $.253^{b}$ & .064 & .031 & 2.33456 & .061 & 3.738 & 1 & 57 & .058 \\
3 & $.275^{c}$ & .075 & .026 & 2.34111 & .011 & .682 & 1 & 56 & .413 \\
\hline
\end{tabular}

Table 14 above can be explained as follows:

a) Model 1, when entering the NOM variable, the predictor contribution is 1.4 percent. The $F$ value of $0.166(p=0.685 ; p>0.1)$ means that NOM cannot predict significantly.

b) Model 2, when entering the variable inflation predictor, contribution increased to 3.1 per cent. The value of $\mathrm{F}$ change is $3.738(\mathrm{p}=0.058 ; \mathrm{p}<0.1)$. This means that independently significant inflation predicts the growth of Islamic banking.

c) Model 3, Moderation 3 (inflation * NOM), can predict the growth variable of Islamic banking by 2.6 per cent. The value of $F$ change is $0.682(p=0.413 ; p>0.1)$. This means that moderation 3 is not able to predict the growth variable of Islamic banking significantly.

Based on the model above, it can be concluded that both individual NOM cannot significantly predict the growth of Islamic banking. Inflation as an independent variable can predict the growth of Islamic banking significantly. However, inflation is not able to moderate the influence between NOM and the growth of Islamic banking.

Table 15. The third MRA Coefficient

\begin{tabular}{lcc}
\hline \multirow{2}{*}{ Model } & \multicolumn{2}{c}{ Unstandardized Coefficients } \\
\cline { 2 - 3 } & $B$ & Std. Error \\
\hline (Constant) & 2,538 & 2,572 \\
NOM & 1,385 & 2,956 \\
Inflation & .664 & .012 \\
InteractionNOM \& Inflation & -.728 & .882 \\
\hline
\end{tabular}

Based on the above Table 15, it can be arranged third MRA equation model as follows. 
$\mathrm{Y}=\alpha+\beta_{1}$ nom $+\beta_{4} \operatorname{Inf}+\beta_{5}$ nom $* \operatorname{Inf}$

$\mathrm{Y}=2,538+1,385 \mathrm{nom}+0,664 \mathrm{Inf}-0,728 \mathrm{nom} *$ Inf.

From the model, it can be concluded that inflation is a moderating variable that can weaken the influence of NOM on Islamic banking growth.

3.2.4. The moderating effect of the inflation variable on the financial performance of the indicator capital adequacy ratio (CAR) on the growth of Islamic banking in Indonesia

The results of the moderated regression analysis (MRA) analysis can be seen in the following table.

Table 16. MRA analysis results of inflation on the effect of CAR on Islamic banking growth

\begin{tabular}{|c|c|c|c|c|c|c|c|c|c|}
\hline \multirow[b]{2}{*}{ Model } & \multirow[b]{2}{*}{$R$} & \multirow[b]{2}{*}{$\begin{array}{c}R \\
\text { Square }\end{array}$} & \multirow{2}{*}{$\begin{array}{c}\text { Adjusted } R \\
\text { Square }\end{array}$} & \multirow{2}{*}{$\begin{array}{l}\text { Std. Error of the } \\
\text { Estimate }\end{array}$} & \multicolumn{5}{|c|}{ Change Statistics } \\
\hline & & & & & $\begin{array}{l}R \text { Square } \\
\text { Change }\end{array}$ & $\begin{array}{c}F \\
\text { Change }\end{array}$ & $d f 1$ & $d f 2$ & $\begin{array}{l}\text { Sig. } F \\
\text { Change }\end{array}$ \\
\hline 1 & $.040^{a}$ & .002 & -.016 & 2.39040 & .002 & .095 & 1 & 58 & .759 \\
\hline 2 & $.217^{b}$ & .047 & .013 & 2.35593 & .045 & 2.710 & 1 & 57 & .105 \\
\hline 3 & $.217^{c}$ & .047 & -.004 & 2.37683 & .000 & .002 & 1 & 56 & .965 \\
\hline
\end{tabular}

Table 16 above can be explained as follows:

a) Model 1, when entering the CAR variable, the predictor contribution is 1.6 per cent. The F value of 0.095 means that CAR cannot predict significantly.

b) Model 2, inflation cannot predict the growth of Islamic banking. This can be seen from the $F$ change value of $2.710(p=0.105 ; p>0.1)$. This means that inflation does not significantly predict the growth of Islamic banking.

c) Model 3, Moderation 4 (inflation * CAR), can predict the Islamic banking growth variable of 0.4 per cent. The value of $F$ change is $0.002(p=0.965 ; p>0.1)$. This means that moderation 4 is not able to predict the growth variable of Islamic banking significantly.

Based on the model above, it can be concluded that both individual CAR and inflation cannot significantly predict the growth of Islamic banking and inflation and cannot moderate the effect of CAR on the growth of Islamic banking.

Table 17. The fourth MRA Coefficient

\begin{tabular}{lcc}
\hline \multirow{2}{*}{ Model } & \multicolumn{2}{c}{ Unstandardized Coefficients } \\
\cline { 2 - 3 } & $\mathrm{B}$ & Std. Error \\
\hline (Constant) & 5,923 & 11267 \\
CAR & -.171 & .756 \\
Inflation & -.638 & 3539 \\
Interaction and InflationCAR & .242 & .011 \\
\hline
\end{tabular}

The above table 17 can be arranged fourth MRA equation model as follows. 
$\mathrm{Y}=\alpha+\beta_{1} \mathrm{CAR}+\beta_{4} \operatorname{Inf}+\beta_{5} \mathrm{CAR} * \operatorname{Inf}$

$\mathrm{Y}=5,923-0,171 \mathrm{CAR}-0,638 \mathrm{Inf}+0,011 \mathrm{CAR} * \operatorname{Inf}$

If viewed from the model, it can be concluded that inflation is a moderating variable that can increase the effect of CAR on sharia banking growth.

3.2.5. The moderating effect of the inflation variable on the influence of the financial performance of the indicator financing deposit ratio (FDR) on the growth of Islamic banking in Indonesia

The results of the moderated regression analysis (MRA) analysis can be seen in the following Table 18.

Table 18. The results of the MRA analysis of inflation on the effect of FDR on the growth of Islamic banking

\begin{tabular}{|c|c|c|c|c|c|c|c|c|c|}
\hline \multirow[b]{2}{*}{ Model } & \multirow[b]{2}{*}{$\mathrm{R}$} & \multirow[b]{2}{*}{$\begin{array}{c}\mathrm{R} \\
\text { Square }\end{array}$} & \multirow[b]{2}{*}{$\begin{array}{l}\text { Adjusted } \\
\text { R Square }\end{array}$} & \multirow[b]{2}{*}{$\begin{array}{l}\text { Std. Error of the } \\
\text { Estimate }\end{array}$} & \multicolumn{5}{|c|}{ Change Statistics } \\
\hline & & & & & $\begin{array}{l}\text { R Square } \\
\text { Change }\end{array}$ & $\begin{array}{c}\mathrm{F} \\
\text { Change }\end{array}$ & df1 & df2 & $\begin{array}{l}\text { Sig. F } \\
\text { Change }\end{array}$ \\
\hline 1 & $.070^{\mathrm{a}}$ & .005 & -.012 & 2.38653 & .005 & .283 & 1 & 58 & .597 \\
\hline 2 & $.212^{\mathrm{b}}$ & .045 & .011 & 2.35835 & .040 & 2.395 & 1 & 57 & .127 \\
\hline 3 & $.212^{\mathrm{c}}$ & .045 & -.006 & 2.37928 & .000 & .002 & 1 & 56 & .968 \\
\hline
\end{tabular}

Table 18 above can be explained as follows:

a) Model 1, when entering the FDR variable, the predictor contribution is 1.2 per cent. The $\mathrm{F}$ value is $0.283(\mathrm{p}=0.597 ; \mathrm{p}>0.1)$. This means that FDR cannot predict the growth of Islamic banking significantly.

b) Model 2, inflation is not able to predict the growth of Islamic banking. This can be seen from the $F$ change value of $2.395(p=0.127 ; p>0.1)$. This means that inflation does not significantly predict the growth of Islamic banking.

c) Model 3, Moderation 5 (inflation * FDR), can predict the Islamic banking growth variable of 0.6 per cent. The value of $F$ change is $0.002(p=0.968 ; p>0.1)$. This means that moderation 5 is not able to predict the growth variable of Islamic banking significantly.

Based on the model above, it can be concluded that both individual FDR and inflation cannot significantly predict the growth of Islamic banking and inflation and cannot moderate the effect of FDR on the growth of Islamic banking. 
Table 19. The fifth MRA Coefficient

\begin{tabular}{lcc}
\hline \multirow{2}{*}{ Model } & \multicolumn{2}{c}{ Unstandardized Coefficients } \\
\cline { 2 - 3 } & $\mathrm{B}$ & Std. Error \\
\hline (Constant) & -3.899 & 26,057 \\
FDR & .083 & .296 \\
Inflation & -.193 & 7,612 \\
Interaction of FDR \& Inflation & -.003 & .085 \\
\hline
\end{tabular}

Based on the Table 19 above, the fifth MRA equation model can be arranged as follows.

$$
\begin{gathered}
\mathrm{Y}=\alpha+\beta_{1} \mathrm{fdr}+\beta_{4} \operatorname{Inf}+\beta_{5} \mathrm{fdr} * \operatorname{Inf} \\
\mathrm{Y}=-3,899+0,083 \mathrm{fdr}-0,193 \operatorname{Inf}-0,003 \mathrm{fdr} * \operatorname{Inf}
\end{gathered}
$$

If viewed from the model, it can be concluded that inflation is a moderating variable that can weaken FDR's influence on Islamic banking growth.

3.2.6. The moderating effect of the inflation variable on the financial performance of the operating expenses income (BOPO) indicator on the growth of Islamic banking in Indonesia

The results of the moderated regression analysis (MRA) analysis can be seen in the following Table 20.

Table 20. The results of the MRA analysis of inflation on the effect of BOPO on the growth of

\begin{tabular}{|c|c|c|c|c|c|c|c|c|c|}
\hline \multirow[b]{2}{*}{$\begin{array}{l}\text { Mo } \\
\text { del }\end{array}$} & \multirow[b]{2}{*}{$\mathrm{R}$} & \multirow[b]{2}{*}{$\begin{array}{c}\text { R } \\
\text { Squar } \\
\text { e }\end{array}$} & \multirow[b]{2}{*}{$\begin{array}{c}\text { Adjusted R } \\
\text { Square }\end{array}$} & \multirow[b]{2}{*}{$\begin{array}{l}\text { Std. Error } \\
\text { of the } \\
\text { Estimate }\end{array}$} & \multicolumn{5}{|c|}{ Change Statistics } \\
\hline & & & & & $\begin{array}{c}\mathrm{R} \\
\text { Square } \\
\text { Change }\end{array}$ & $\begin{array}{c}\text { F } \\
\text { Chang } \\
\text { e }\end{array}$ & df1 & $\mathrm{df} 2$ & $\begin{array}{l}\text { Sig. F } \\
\text { Change }\end{array}$ \\
\hline 1 & $0.014^{\mathrm{a}}$ & .000 & -.017 & 2.39212 & .000 & .011 & 1 & 58 & .916 \\
\hline 2 & $.213^{\mathrm{b}}$ & .045 & .012 & 2.35784 & .045 & 2.699 & 1 & 57 & .106 \\
\hline 3 & $.219^{c}$ & .048 & -.003 & 2.37553 & .003 & .154 & 1 & 56 & 696 \\
\hline
\end{tabular}
Islamic banking

Table 20 above can be explained as follows:

a) Model 1, when entering the BOPO variable, the predictor contribution is 0.000 per cent. The F value is $0.011(\mathrm{p}=0.916 ; \mathrm{p}>0.1)$. This means that BOPO cannot predict the growth of Islamic banking significantly.

b) Model 2, inflation cannot predict the growth of Islamic banking. This can be seen from the $F$ change value of $2.699(p=0.106 ; p>0.1)$. This means that inflation does not significantly predict the growth of Islamic banking. 
c) Model 3, Moderation 6 (inflation * BOPO), can predict the growth variable of Islamic banking by 4.8 per cent. The value of $F$ change is $0.154(p=0.696 ; p>0.1)$. This means that moderation 6 is not able to predict the growth variable of Islamic banking significantly.

Based on the above model, it can be concluded that both individual BOPO and inflation cannot significantly predict the growth of Islamic banking and inflation and cannot moderate the effect of BOPO on the growth of Islamic banking.

Table 21. Sixth MRA Coefficient

\begin{tabular}{lcc}
\hline \multirow{2}{*}{ Model } & \multicolumn{2}{c}{ Unstandardized Coefficients } \\
\cline { 2 - 3 } & \multicolumn{1}{c}{ Std. Error } \\
\hline (Constant) & 11406 & 38200 \\
BOPO & -.086 & .399 \\
Inflation & -5061 & 11792 \\
Interaction BOPO \& Inflation & .048 & .123 \\
\hline
\end{tabular}

Based on the above Table 21, it can be arranged MRA sixth equation model as follows.

$\mathrm{Y}=\alpha+\beta_{1}$ Bopo $+\beta_{4} \operatorname{Inf}+\beta_{5}$ Bopo $* \operatorname{Inf}$

$\mathrm{Y}=11,406-0,086$ bopo $-5,061 \operatorname{Inf}+0,048$ bopo $*$ Inf.

From this model, it can be concluded that inflation is a moderating variable that can strengthen the influence of BOPO on Islamic banking growth.

\subsection{Discussion}

This study aims to determine and analyze the impact of inflation as a moderating variable of financial performance on the growth of Islamic banking in Indonesia. This is important to study so that Islamic banking gets an overview of the impact of inflation so that decision making can be carried out appropriately and correctly. The financial performance used in this study consists of return on assets (ROA), non-performing financing (NPF), net operating margin $(\mathrm{NOM})$, capital adequacy ratio (CAR), financing to deposit ratio (FDR), and operating expenses revenue expense. (BOPO).

In the first analysis, it is found that inflation can strengthen the influence of return on assets on Islamic Banking Growth. Inflation is not a moderating variable, but significant inflation (with a negative slot) affects the growth of Islamic banking as an independent variable. These results provide an understanding that if inflation increases, the growth of Islamic banking will decrease. Vice versa, if inflation decreases, the growth of Islamic banking will increase. Meanwhile, as an independent variable, the return on assets variable is not significant in influencing the growth of Islamic banking.

Return on assets is a financial ratio that aims to determine how much the contribution of assets generates net income. The increased return on assets is the hope of business actors; Return on assets can determine the investor's decision whether to invest or not. High return on 
assets is considered to be able to generate high profits as well. In connection with the findings of this study, it means that during the research period, the contribution of return on assets to the growth of Islamic banking did not have a significant impact. In contrast to return on assets, Inflation has a negative slope contribution to the growth of Islamic banking. This illustrates that to increase the growth of Islamic banking, inflation must be controlled.

These findings are consistent with the results of research conducted by Supriyanto \& Sari (2019), which states that return on assets does not affect the growth of Islamic banking. In addition, the research results of Setiawan \& Hanryono (2016) also found that inflation affects profit growth.

In the second analysis, it was found that inflation could weaken the influence of nonperforming financing (NPF) on the growth of Islamic banking. NPF is not significant in influencing the growth of Islamic banking. Inflation is not significant as a moderating variable and also not significant as an independent variable. This gives an understanding that even if the NPF value increases or decreases, it will not significantly affect the growth of Islamic banking. Inflation will also not have a significant effect, although this effect can weaken the influence of NPF on the growth of Islamic banking.

Non-performing financing is a ratio used to determine how capable banking management is in managing non-performing financing. Financing disbursed by banks has uncertainties that can become a problem at any time due to default. This is a business risk that must be borne by banks. A high NPF illustrates the increasing number of non-performing financing, which means the more low financing disbursed. In Bank Indonesia regulations, the NPF has a maximum threshold of 5 per cent. Similar to the NPF, inflation is a macroeconomic condition that cannot be determined with certainty. When inflation increases, which means an increase in prices over a certain period, people who have a fixed income and have loans from banks will find it difficult to make payments. So this could be the cause of the increase in problematic financing.

These findings are consistent with the research results conducted by Dhiba \& Esya (2019) and Safrida \& Abror (2011), which state that the NPF is not significant in influencing the growth of Islamic banking assets in Indonesia. In addition, the research results of Setiawan \& Hanryono (2016) also found that inflation affects profit growth.

In the third analysis, it was found that inflation weakened and was not significant as a moderator of the influence of net operating margin (NOM) on the growth of Islamic banking. However, the inflation variable is significant (positive slot) as an independent variable affecting the growth of Islamic banking. This means that if inflation increases, NOM will decrease. Conversely, if inflation decreases, NOM will increase.

Net operating margin is the ratio used to measure bank management's ability to manage its productive assets to generate revenue sharing. These findings are consistent with research conducted by Ihsan (2019) which states that the Net operating margin (NOM) is not significant in influencing the growth of Islamic banking. In addition, the research results of Setiawan \& Hanryono (2016) also found that inflation affects profit growth.

In the fourth analysis, it is found that inflation can strengthen the effect of the capital 
adequacy ratio (CAR) on the growth of Islamic banking. CAR individually is not able to influence the growth of Islamic banking. Inflation is not significant as a moderating variable and also not significant as an independent variable. This gives an understanding that the capital adequacy ratio does not significantly affect changes in the growth of Islamic banking. The increase or decrease in the growth of Islamic banking is not caused by changes in the capital adequacy ratio. Inflation was not able to moderate this influence.

Capital adequacy ratio is one of the ratios used to determine the bank's ability to maintain capital and identify measures and control risks that may arise to the amount of bank capital (Prasanjaya \& Ramantha, 2013).

These findings are consistent with the research results conducted by those who found that the capital adequacy ratio (CAR) did not significantly affect profit growth. In addition, the research results of Setiawan \& Hanryono (2016) also found that inflation affects profit growth.

In the fifth analysis, it was found that inflation could weaken the influence of the financing to deposit ratio (FDR) on the growth of Islamic banking. Financing to deposit ratio individually is not significant in influencing the growth of Islamic banking. Inflation is not significant as a moderating variable and also not significant as an independent variable. This provides an understanding that an increase or decrease in the financing to deposit ratio will not change the growth of Islamic banking.

Financing to deposit ratio is one of the ratios used to determine the number of funds disbursed to the number of third party funds collected. Based on the provisions of Bank Indonesia, a good FDR value is between 80 per cent and 110 per cent, so Islamic banking is not effective in channelling its funds. Because in Islamic banking, there is a hoarding of funds that do not produce. Meanwhile, suppose the amount of funds disbursed is higher than the number of third party funds collected. In that case, it means that Islamic banking is also ineffective because the high financing disbursed is vulnerable to non-performing financing (Candera, 2018).

These findings are consistent with the research results conducted by Setyawati \& Suroso (2016), which states that FDR has a negative and insignificant effect on the growth of total Islamic banking assets in Indonesia. In addition, the research results of Setiawan \& Hanryono (2016) also found that inflation affects profit growth.

In the last analysis, it was found that inflation could weaken the effect of operating expenses on revenue (BOPO) on the growth of Islamic banking. As an independent variable, Operating Expenses Revenue Expenses are not significant in influencing the growth of Islamic banking. Inflation is not significant as a moderating variable and also not significant as an independent variable. This gives an understanding that BOPO does not significantly affect increasing or decreasing the growth of Islamic banking.

Operating Expenses Revenue Expense is a ratio used to determine the efficiency and ability of banks to carry out their operations. BOPO can reduce total assets, and this is because the main activity of banking is as a financial intermediary. These activities consist of activities to collect funds from customers through savings, and then the next activity is to distribute funds 
through financing. From these two activities, the bank will get interest costs and interest yields. A faithful increase in operating costs will result in reduced profit before tax. This will reduce profits or profitability, which will also reduce total assets.

These findings are consistent with the results of research conducted by Dhiba and Esya (2019), which states that BOPO has a positive and insignificant relationship to the growth of Islamic banking assets in Indonesia in the short and long term. In addition, the research results of Setiawan \& Hanryono (2016) also found that inflation affects profit growth.

\section{Conclusion}

Based on the results of the analysis above, it can be concluded that:

1. Inflation cannot moderate the effect of return on assets on the growth of Islamic banking in Indonesia. Inflation can only be a predictor of Islamic banking growth.

2. Inflation cannot moderate the influence of non-performing financing on the growth of Islamic banking in Indonesia. Inflation is also not able to be a predictor of Islamic banking growth.

3. Inflation cannot moderate the influence of net operating margin on the growth of Islamic banking in Indonesia. Inflation can only be a predictor of Islamic banking growth.

4. Inflation cannot moderate the effect of the capital adequacy ratio on the growth of Islamic banking in Indonesia. Inflation can only be a predictor of Islamic banking growth.

5. Inflation cannot moderate the influence of the financing to deposit ratio on the growth of Islamic banking in Indonesia. Inflation is also not able to be a predictor of Islamic banking growth.

6. Inflation cannot moderate the effect of Operating Expenses on Operating income on the growth of Islamic banking in Indonesia. Inflation is also not able to be a predictor of Islamic banking growth.

\section{References}

Aisy, D.R \& Mawardi, Imron. (2016). Faktor-Faktor yang Mempengaruhi Pertumbuhan Aset Bank Syariah di Indonesia tahun 2006-2015. Jurnal Ekonomi Syariah Teori dan Terapan, 3(3), 249-265.

Candera, M. (2018). Faktor-faktor yang mempengaruhi financing to deposit ratio pada Perbankan Syariah di Provinsi Jambi. Jurnal Motivasi, 3(2), 461-476.

Candera, M., Amir, A., \& Artis, D. (2015). Pengaruh dana pihak ketiga, non performing financing, dan financing to deposit ratio terhadap pembiayaan perbankan syariah di Provinsi Jambi. e-jurnal perspektif ekonomi dan pembangunan daerah, 4(1), 1-10.

Dhiba, N.A., \& Esya, L. (2019). Pengaruh NPF, BOPO, GDP, dan SBIS terhadap pertumbuhan aset Perbankan Syariah di Indonesia. Media Ekonomi, 27(1), 9-16.

Fahmi, I. (2011). Analisis Laporan Keuangan. Alphabeta. 
Fahmi, I. (2017). Analisa Kinerja Keuangan. Alphabeta.

Ghozali, I. (2013). Aplikasi Analisis Multivariate dengan Program SPSS 21. BP Undip.

Hery. (2017). Teori Akuntansi Pendekatan Konsep dan Analisis. PT. Grasindo.

Ichsan, A., Amri, M., \& Rahmatia. (2014). Hubungan kinerja keuangan, profitabilitas, dan pertumbuhan aset Bank Pembangunan Daerah (BPD) di Indonesia. Jurnal Analisis, 3(2), 195-200.

Ihsan, D. (2019). Hubungan ekspansi jaringan kantor dan kinerja keuangan terhadap pertumbuhan aset Bank Syariah. Akuntabilitas: Jurnal Ilmu Akuntansi, 12(1), 119128.

Kasmir. (2014). Analisis Laporan Keuangan. Rajawali Press.

Prasanjaya, A., \& Ramantha, I. (2013). Analisis pengaruh CAR, BOPO, LDR, dan ukuran perusahaan terhadap profitabilitas bank yang terdaftar di BEI. E-Jurnal Akuntansi Universitas Udayana, 4, 230-245.

Priyo, Estika Maulida and Sampurno, R Djoko (2013). Analisis Pengaruh Return On Asset, Debt To Equity Ratio, Firm Size, Growth dan Free Cash Flow Terhadap Devidend Payout Ratio (Studi Empiris pada Perusahaan Manufaktur yang Terdaftar di BEI Periode 2008-2011). Undergraduate thesis, Fakultas Ekonomika dan Bisnis.Semarang: Universitas Diponegoro.

Setiawan, D.I., \& Hanryono. (2016). Analisis pengaruh kinerja keuangan bank, tingkat inflasi, dan bi rate terhadap pertumbuhan laba (studi pada Bank Swasta Devisa yang terdaftar pada Bursa Efek Indonesia Periode 2009-2013). Journal of Accounting and Business Studies, 1(1), 21-37.

Setyawati, I., \& Suroso, S. (2016). Determinants growth of total assets by bank specific variable and market share in Islamic Banking in Indonesia, Period 2011-2015. Journal of Economic Education, 5(1), 52-68.

Sugiyono. (2014). Metode Penelitian Bisnis, Kuantitatif, Kualitatif, dan R\&D. Alfabeta.

Sukirno, S. (2012). Mikroekonomi: Teori Pengantar. Rajagrafindo Persada

Supriyanto, B., \& Sari, SP (2019). Faktor-faktor internal yang mempengaruhi pertumbuhan aset Bank Umum Syariah di Indonesia Selama Satu Dekade (2009-2018). Seminar Nasional \& Call For Paper Seminar Bisnis Magister Manajemen (SAMBIS-2019) "Membangun Ekonomi Kreatif yang Berdaya Saing" ISSN: 2685-1474 (https://publikasiilmiah.ums.ac.id/bitstream/handle/11617/11102/31.\%20Bagas\%20d $\underline{\text { an } \% 20 \text { Shinta_.pdf? sequence }=1 \& \text { isAllowed }=y \text { ) }}$

Sutrisno. (2013). Manajemen Keuangan. Ekonosia.

Syafrida, I., \& Abror, A. (2011). Faktor-Faktor Internal dan Eksternal yang Mempengaruhi Pertumbuhan Aset Perbankan Syariah di Indonesia. Jurnal Ekonomi dan Bisnis, 10(1), 19-24. 
Vol. 1, No. 2, December 2020

\section{Copyrights}

Copyright for this article is retained by the author(s), with first publication rights granted to the journal.

This is an open-access article distributed under the terms and conditions of the Creative Commons Attribution license http://creativecommons.org/licenses/by/4.0/ 